\title{
Interrecurrent nerve anastomosis with free nerve graft transposition in rabbits
}

\section{Tavşanlarda serbest sinir grefti transpozisyonu ile interrekürren sinir anastomozu}

\author{
Bülent ÇALIK ${ }^{1}$, Ömer ENGİN², Aslı MURATLI ${ }^{3}$, Can Ahmet KULAN ${ }^{4}$, Buket TOPÇU ${ }^{5}$, Kerem KARAMAN ${ }^{6}$, \\ Fuat İPEKÇi ${ }^{1}$, Gökçe AKSOY YILDIRIM ${ }^{7}$, Mutlu ÜNVER ${ }^{8}$
}

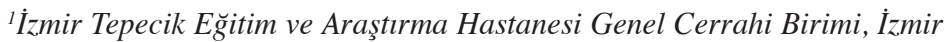

${ }^{2}$ İzmir Buca Seyfi Demirsoy Devlet Hastanesi, İzmir

${ }^{3}$ İzmir Başkent Üniversitesi Zübeyde Hanım Hastanesi Patoloji Birimi, İzmir

${ }^{4}$ İzmir Bozyaka Ĕ̆itim ve Araştırma Hastanesi Nöroloji Birimi, İzmir

${ }^{5}$ İzmir Bozyaka Ĕ̆itim ve Araştırma Hastanesi Anesteziyoloji Birimi, İzmir

${ }^{6}$ Sakarya Üniversitesi Tıp Fakültesi Genel Cerrahi Anabilim Dalı, İzmir

${ }^{7}$ Ankara Dışkapı Eğitim ve Araştırma Hastanesi Kulak-Burun-Boğaz Birimi, İzmir

${ }^{8}$ Izmir University, Faculty of Medicine, Department of General Surgery, İzmir

\begin{abstract}
Objective: In this experimental study, we aimed to observe the effect of interrecurrent free nerve graft transposition performed after iatrogenic transection of the recurrent laryngeal nerve on the improvement of vocal cord function in rabbits.

Methods: The study consisted of 2 groups as the experimental, and control groups each containing 8 rabbits. The right recurrent nerve was transected both in the control and experiment groups. Inter-recurrent free nerve graft transposition using sural nerve was performed with end-to-side anastomosis in the experimental group whereas in the control group, nerve reconstruction was not performed.

Results: After the $3^{\text {rd }}$ postoperative month, the right vocal cord activity was recorded in the experimental group using videolaryngoscopy (VLS) and intramuscular electromyography (EMG). In contrast to the control group, no vocal cord muscle atrophy was found during light microscopic examination in the rabbits of the experimental group.

Discussion: Inter-recurrent free nerve graft transposition is an acceptable method which can be considered in patients with iatrogenic recurrent nerve transection.
\end{abstract}

Keywords: End- to- side nerve anastomosis, free nerve graft, laryngeal re-innervation, nerve transposition, recurrent nerve, vocal cord palsy, vocal cord paralysis.

\section{$\ddot{\mathbf{O Z Z}}$}

Amaç: Bu deneysel çalışmada, tavşanlarda rekürren laringeal sinirin iyatrojenik kesisini takiben serbest sinir grefti ile interrekürren sinir transpozisyonunun vokal kord fonksiyonlarının iyileşmesi üzerindeki etkisini gözlemlemeyi amaçladık.

Yöntem: Çalışma her biri 8 tavşan içeren deney ve kontrol grubu olmak üzere iki gruptan oluşuyordu. Her iki grupta da să̆ rekürren sinir kesildi. Deney grubunda sural sinir kullanılarak interrekürren serbest sinir transpozisyonu uç-yan anastomoz ile yapıldı. Kontrol grubunda ise sinir rekonstrüksiyonu yapılmadı.

Bulgular: Postoperatif üçüncü aydan sonra sağ vokal kord aktivitesi deney grubunda videolaringoskopi (VLS) ve kas içi elektromiyografi (EMG) kullanılarak kaydedildi. Kontrol grubunun aksine deney grubu tavşanlarında ışık mikroskobunda vokal kord kas atrofisi görülmedi.

Sonuç: Inter-rekürren serbest sinir grefti transpozisyonu iyatrojenik rekürren sinir kesisi olan hastalarda kabul edilebilir bir yöntemdir.

Anahtar kelimeler: Uç-yan sinir anastomozu, serbest sinir grefti, laringeal yeniden innervasyon, sinir transpozisyonu, rekürren sinir, vokal kord palsi, vokal kord paralizisi
Alındığı tarih: 04.04.2016

Kabul tarihi: 18.10 .2017

Yazışma adresi: Uzm. Dr. Bülent Çalık, 100/1 Sokak No: 32, Kat: 4, Daire: 13, Banu Apt. Göztepe - Konak - 35290 - İzmir - Türkiye e-mail: calikbulentdr@yahoo.com 


\section{INTRODUCTION}

One of the complications of thyroid surgery is inadvertent transection of the recurrent nerve. Within the last 25 years, subtotal thyroidectomy has been replaced by total thyroid lobectomy in patients with benign multinodular goiter, Graves' disease, and thyroid cancer. The principal change in the operative technique has been to move from "lateral dissection" to "capsular dissection" ${ }^{(1,2)}$. The incidence of recurrent laryngeal nerve injury has been reported as between $1-2 \%$ across different thyroid surgery centers. The incidence rates tend to increase when thyroidectomy is performed by less experienced surgeons, or when thyroidectomy is done for recurrent goiters or malignant diseases ${ }^{(3-6)}$.

Intraoperatively, visualizing the cut nerve is extremely difficult. If seen, the proximal and distal ends may be sutured together. However, if this is not the case, atrophy of the vocal cords is imminent with a high likelihood of requiring tracheostomy particularly in bilateral injuries. Therefore, we aimed to improve vocal cord function by performing interrecurrent nerve transposition with free nerve grafting, in order to transfer the nerve impulses from the intact stable nerve to the disrupted nerve. If nerve transposition can achieve these results, then vocal cord contraction with breathing, and subsequent respiratory obstruction will not occur.

\section{MATERIAL and METHODS}

After obtaining approval from our institutional ethics board (Ege University, Approval No. 2010$83)$, the experimental and control groups were designed. A total of 16 New Zealand white rabbits ( 8 per group) were utilized. Intravenous cefazolin (30 mg/ $\mathrm{kg}$ /day) was injected through peripheral ear vein 30 minutes before operation. The operation was performed under general anesthesia with intamuscular ketamine $(90 \mathrm{mg} / \mathrm{kg})$ and xylazine $(3 \mathrm{mg} / \mathrm{kg})$ injections. Surgical operation was performed using magnifying glasses under 5x magnification (Look's 5000 model). Rabbits' hair was shaved. Operative area was cleaned by povidone-iodine $(10 \%)$ solution. Sural nerves were identified in right hind legs of rabbits. Skin flaps were created after performing a Kocher's collar incision and retracting the pretracheal muscles laterally. The right recurrent laryngeal nerve was identified and transected below the inferior portion of the thyroid gland. In the control group, after nerve transection, muscle layers were closed and the operation was terminated. In the experimental group, after nerve transection, the left recurrent nerve was identified. The proximal end of the free nerve graft was anastomosed to the left recurrent nerve in an end-toside fashion with 10/0 prolene sutures. The distal end of the free nerve graft was anastomosed to the laryngeal portion of the right recurrent nerve, in an endto-end fashion, also with 10/0 prolene sutures.

\section{Otorhinolaryngologic examination}

Videolaryngoendoscopy was performed under general anesthesia using ketamine injections during spontaneous respirations. All of the rabbits were subjected to a videolaryngoscopic examination to evaluate their cord activity on the first pre-and postoperative days and after the $3^{\text {rd }}$ postoperative month.

\section{Intramuscular EMG examination}

All rabbits in the experimental, and the control groups were examined 3 months after the procedure placing a concentric needle electrode at both vocal cords under ketamine anesthesia. The vocal cords were reached through the cricothyroid membrane. After sacrification of the animal, vocal cord denervation and reinnervation was assessed during electromyography using a Medelec Sapphire 4ME and Medelec Synergy electromyograph. (EMG) Examinations were recorded as video display and EMG tracings. EMG examinations yielded qualitative data.

\section{Histopathologic examination}

Samples were fixed in neutral buffered formalin (10\% formaldehyde). Following the fixation procedure, the tissue samples were trimmed and processed using standard paraffin-embedding methods. Sections were cut at $4 \mu \mathrm{m}$, and then stained with hematoxylineosin. Histopathologic examination of the samples 
was carried out using a light microscope, and under magnification (Carl Zeiss Axioscope photomicroscope, Carl Zeiss Axiocam ICc3 3.3 Mp digital camera and Carl Zeiss Axiovision software).

At the end of the study period, animals were sacrificed using intravenous infusion of high dose ketamine $(70 \mathrm{mg} / \mathrm{kg})$.

\section{Statistical Analysis}

Data analysis was performed by using SPSS for Windows, version 11.5 (SPSS Inc., Chicago, IL, United States). Fisher's exact test was used to detect differences between groups based on otorhinolaryngologic, EMG and pathologic examination results. A $P$ value less than $<0.05$ was considered as statistically significant.

\section{RESULTS}

\section{Surgical outcomes}

On the 1st postoperative day, all rabbits were active and in good condition After the $3^{\text {rd }}$ postoperative month, no complications such as wound infections or hematomas were detected before resorting to videoendoscopic and EMG examinations.

\section{Laryngologic outcomes}

All rabbits have preoperatively normal bilateral vocal cord activities. However, on the $1^{\text {st }}$ postoperative day, the right vocal cords were fixed both in the experimental and control group rabbits. After the $3^{\text {rd }}$ postoperative month, right vocal cord fixation persisted in the control group rats. On the other hand, all rats in the experimental group had a minimal right cord activity $(\mathrm{p}<0.001)$.

\section{EMG outcomes}

In the experimental group, the EMG recordings of the left vocal muscles were within normal limits in all rabbits of the experimental group. Along with denervation activities on symptomatic right vocal cord muscles, there was motor unit discharges synchronous with respirations. These findings were evaluated in favour of regeneration (Figure 1). Intensive total denervation potentials were observed in symptomatic right vocal cord muscles in all 8 rabbits of the control group. There was no motor unit activity synchronous with respirations in any of these muscles (Figure 2). However, normal motor unit activities synchronous with respiration were observed in the left vocal muscles both in the experimental and control groups $(\mathrm{p}<0.001)$.

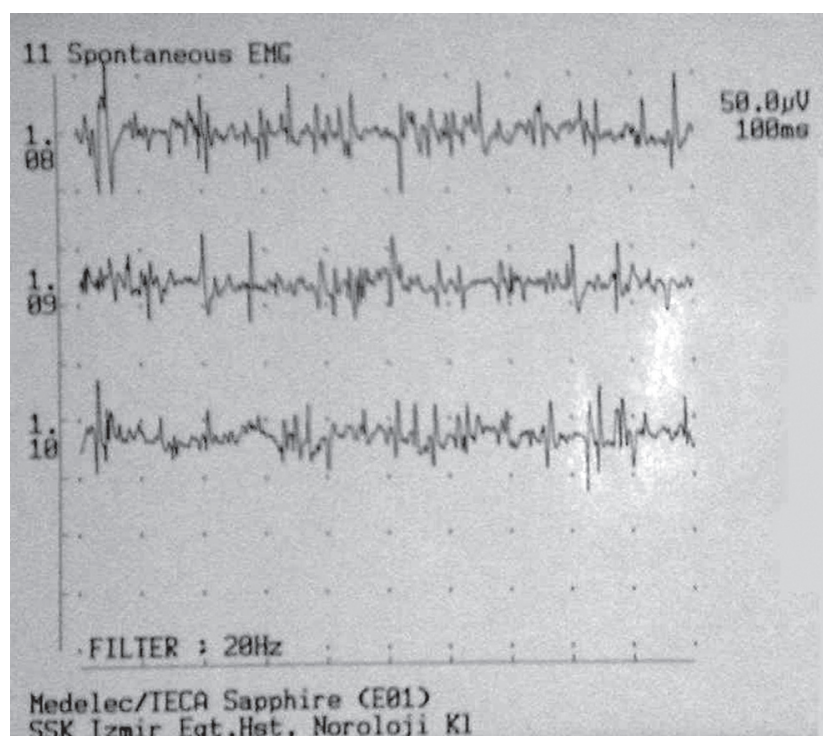

Figure 1. The EMG findings of the vocal cord muscles in the experimental group which show the postoperative regeneration potential.

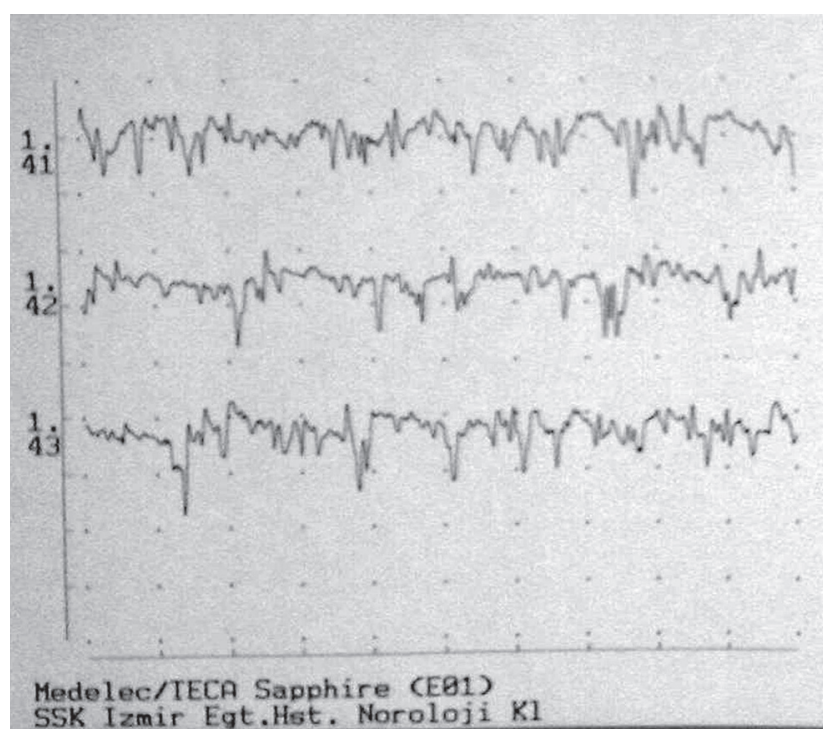

Figure 2. Total denervation in vocal cord muscles of the control group was detected by EMG. 


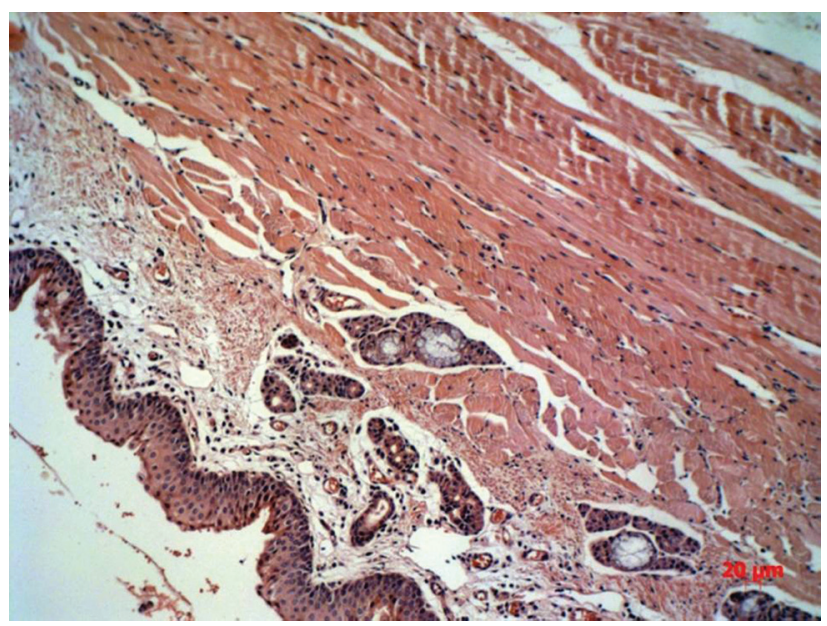

Figure 3. No muscular atrophy is detected in the experimental group (HE X 100).

\section{Pathologic Outcomes}

Both in the experimental and control groups, no atrophy was detected in the left hemilarynx. No right vocal cord muscle atrophy was detected in the rabbits of the experimental group (Figure 3), whereas in all cases of the control group, atrophy was seen in the right hemilarynx (Figure 4), (Table 1), $(\mathrm{p}<0.001)$.

Table 1. Comparison of the experimental group with the control group.

\begin{tabular}{lccc}
\hline Variables & $\begin{array}{c}\text { Control } \\
\text { Group }\end{array}$ & $\begin{array}{c}\text { Experimental } \\
\text { Group }\end{array}$ & $\begin{array}{c}\text { P } \\
\text { value }\end{array}$ \\
\hline $\begin{array}{l}\text { Laryngoscopy } \\
\quad \text { Vocal cord movement }\end{array}$ & - & $8(100 \%)$ & $<0.001$ \\
$\quad$ No vocal cord movement & $8(100 \%)$ & - & \\
EMG & $8(100 \%)$ & - & $<0.001$ \\
$\quad$ Nerve denervation & - & $8(100 \%)$ & \\
$\quad$ Nerve regeneration & & & \\
$\begin{array}{l}\text { Pathologic examination of } \\
\text { the larinx }\end{array}$ & $8(100 \%)$ & - & $<0.001$ \\
$\quad \begin{array}{l}\text { Presence of atrophy } \\
\text { No atrophy }\end{array}$ & - & $8(100 \%)$ & \\
& & &
\end{tabular}

EMG: Electromyelography

\section{DISCUSSION}

Recurrent nerve transection is characterized by a loss of vocal cord movement, a forward-tilted arytenoid cartilage, and bowing of the vocal cord due to loss of muscle tone ${ }^{(7)}$. One of the approaches to treat

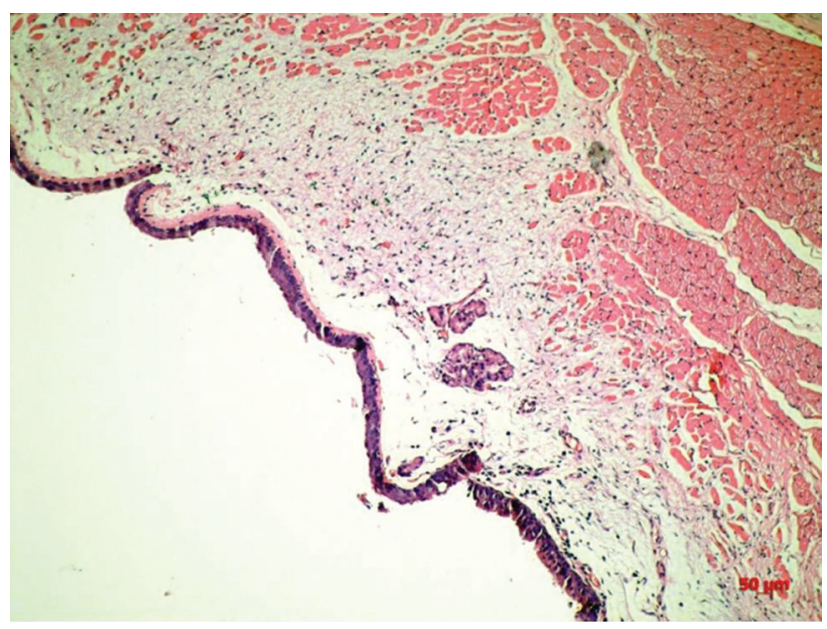

Figure 4. Muscular atrophy is observed in the control group (HE X 50).

this complication is laryngeal reinnervation. Laryngeal reinnervation refers to any method that seeks to reestablish neural pathways to the vocal cord which includes use of nerve-muscle pedicle, muscle-nervemuscle pedicle, and donor nerve-recurrent laryngeal nerve (RLN) anastomosis ${ }^{(8-10)}$.

End-to-end microsurgical neurorhaphy has become the standard approach for the repair of peripheral nerve injuries. However, when the proximal stump is unavailable, or when autogenous donor nerve is not of adequate length, then, this method becomes unsuitable ${ }^{(11)}$.

Animal experiments and clinical trials have shown that end-to-side repair of transected nerves may result in functional motor re-innervation through the collateral sprouting of axons. Even partial recovery of sensory function after surgically created end-to-side nerve anastomosis has been reported. The advantage of the end-to-side neurorrhaphy is that nerve function of the recipient nerve can be restored, while avoiding damage to the donor nerve ${ }^{(12-16)}$.

Bontioti et al. (17) have investigated the factors effective on the mechanism of action of end-to-side nerve repair, and suggested three basic mechanisms: 1. contamination from axons regenerating from the proximal stump of the recipient nerve, 2. true collateral sprouting from healthy fibers of the donor nerve and 3. "terminal sprouting" also called, true axonal regeneration from damaged fibers of the donor nerve. 
Collateral sprouting from healthy fibers does not need the induction from donor nerve trauma, but simple coaptation with the chemical call from the degenerated distal stump and from the distal effector is capable to induce axonal ingrowth from the healthy fibers of the donor nerve trunk . Contamination can sometimes result in a neuroma which should be taken into account. It does not require the donor nerve damage collateral sprouting from wholesome nerve fibers: simple coaptation with the chemical call from the degenerated distal stump and from the distal effector is capable to induce axonal ingrowth from the healthy fibers of the donor nerve trunk. The third mechanism involves trauma to the donor nerve: terminal sprouting can be produced either opening a window in the nerve trunk connective tissue, or passing classical suture stitches though/around ${ }^{(17,18)}$.

The only real functioning abductor muscle of the vocal cords is the posterior cricoarytenoid muscle. The recurrent laryngeal nerve innervates all of the intrinsic muscles of the larynx, except the cricothyroid muscle ${ }^{(19)}$. Recurrent nerve transection is a serious complication, as it leads to vocal cord paralysis, and the ipsilateral vocal cord remains fixed in the paramedian position ${ }^{(20)}$. The vocal cords should be evaluated preoperatively in order to determine whether vocal cord paralysis is already present. Furthermore, the recurrent laryngeal nerve should be routinely identified during thyroidectomy or parathyroidectomy.

During thyroidectomy, it becomes difficult to identify the recurrent nerve when all arteries and veins are transected. The surgeon should be alerted for possible iatrogenic injury to the recurrent nerve if there is no lumen identified in one of these transected structures. In the previous animal study by Engin et al. ${ }^{(21)}$ an end-to-end anastomosis was performed between the phrenic and recurrent laryngeal nerves, and the vocal cord function was demonstrated with videolaryngoendoscopy and laryngeal EMG, with an up to $90 \%$ success rate. Despite these results, this operation is not recommended in elderly patients particularly in those with compromised respiratory function. However, the present nerve transposition experiment was designed to be used in such cases. We created a model of unilateral recurrent nerve paralysis with contour lateral recurrent stimuli directed to vocal cords via nerve transposition. Stimulation of the vocal cords induced reinnervation of denervated muscles, and they regained their respiratory function. The sural nerve is used because of its functionality as free nerve graft. Although, not identified on the first postoperative day, vocal cord activity and reinnervation potentials were detected on EMG after 3 months with a success rate of $100 \%$ without subsequent laryngeal atrophy. Following recurrent nerve transection, nerve transposition successfully restored laryngeal function in rabbits.

\section{CONCLUSION}

In conclusion, inter-recurrent nerve anastomosis with free nerve grafting can be considered in patients with unilateral recurrent nerve transection injury, particularly, when the complications of tracheostomy and the quality of life are taken into consideration.

Conflicts of interest

The authors have no conflicts of interest to declare.

Financial Disclosure: The authors state that all financial and material support for this research and work was provided by their own means without any additional financial contribution.

\section{REFERENCES}

1. Zheng S, Xu Z, Wei Y, Zeng M, He J. Effect of intraoperative neuromonitoring on recurrent laryngeal nerve palsy rates after thyroid surgery-A meta-analysis. J Formos Med Assoc 2013;112:463-72.

https://doi.org/10.1016/j.jfma.2012.03.003

2. Delbridge L. Total thyroidectomy: the evolution of surgical technique. ANZ J Surg 2003;73:761-8. https://doi.org/10.1046/j.1445-2197.2003.02756.x

3. Efremidou EI, Papageorgiou MS, Liratzopoulos N, Manolas KJ. The efficacy and safety of total thyroidectomy in the management of benign thyroid disease: a review of 932 cases. Can J Surg 2009;52:39-44.

4. Mishra A, Agarwal G, Agarwal A, Mishra SK. Safety and efficacy of total thyroidectomy in hands of endocrine surgery trainees. Am J Surg 1999;178:377-80. https://doi.org/10.1016/S0002-9610(99)00196-8

5. Netterville JL, Aly A, Ossoff RH. Evaluation and treatment of complications of thyroid and parathyroid surgery. Otolaryngol Clin North Am 1990;23:529-52.

6. Snyder SK, Lairmore TC, Hendricks JC, Roberts JW. 
Elucidating mechanisms of recurrent laryngeal nerve injury during thyroidectomy and parathyroidectomy. J Am Coll Surg 2008;206:123-30. https://doi.org/10.1016/j.jamcollsurg.2007.07.017

7. Lee WT, Milstein C, Hicks D, Akst LM, Esclamado RM. Results of ansa to recurrent laryngeal nevre reinnervation. Otolaryngology-Head and Neck Surgery 2007;136:450-4. https://doi.org/10.1016/j.otohns.2006.11.040

8. Marina MB, Marie JP, Birchall MA. Laryngeal reinnervation for bilateral vocal fold paralysis. Current Opinion in Otolaryngology \& Head and Neck Surgery 2011;19:434-8. https://doi.org/10.1097/MOO.0b013e32834c7d30

9. Paniello RC. Laryngeal reinnervation. Otolaryngol Clin $N$ Am 2004;37:161-81. https://doi.org/10.1016/S0030-6665(03)00164-6

10. Lorenz RR, Esclamado RM, Teker AM, Strome M, Scharpf J, Hicks D, Milstein C, Lee WT. Ansa Cervicalis-to-Recurrent Laryngeal Nerve Anastomosis for Unilateral Vocal Fold Paralysis: Experience of a Single Institution. Annals of Olology, Rhinology \& Laryngology 2008;117:40-5. https://doi.org/10.1177/000348940811700109

11. Kim BS, Choy WS, Chung MS, Baek GH. Modified End-toSide Neurorrhaphy Enhances Axonal Sprouting: A Motor Functional and Morphological Study. Orthopedics 2007;30:853-8.

12. Bontioti E, Kanje M, Lundborg G, Dahlin LB. End-to-side nerve repair in the upper extremity of rat. Journal of the Peripheral Nervous System 2005;10:58-68. https://doi.org/10.1111/j.1085-9489.2005.10109.x

13. Bontioti E, Dahlin LB, Kataoka K, Kanje M. End-to-side nerve repair induces nuclear translocation of activating transcription factor 3. Scand J Plast Reconstr Surg Hand Surg 2006;0:321-8. https://doi.org/10.1080/02844310600999956

14. Xiong G, Ling L, Nakamura R, Sugiura Y. Retrograde tracing and electrophysiological findings of collateral sprouting after end-to-side neurorrhaphy. Hand Surgery 2003;8:145-50. https://doi.org/10.1142/S0218810403001637

15. Rebol J, Milojkovic V, Didanovic V. Side-to-end hypoglossalfacial anastomosis via transposition of the intratemporal facial nerve. Acta Neurochir (Wien) 2006;148:653-7. https://doi.org/10.1007/s00701-006-0736-2

16. Colonna M, Russo A, Galeano M, Delia G, Pajardi G, d'Alcontres FS. "Baby sitting" procedures in proximal nerve trunk injuries: A review of graft bridging techniques at the level of forearm and a personal approach. Plast Aesth Res. In Press. 2016.

17. Bontioti E, Dahlin LB. Mechanisms underlying the end-toside nerve regeneration. Int Rev Neurobiol 2009;87:251-268. https://doi.org/10.1016/S0074-7742(09)87012-8

18. Wood MD, Mackinnon SE. Pathways regulating modalityspecific axonal regeneration in peripheral nerve. Exp Neurol 2015;265:171-175. https://doi.org/10.1016/j.expneurol.2015.02.001

19. Jacobs IN, DelGaudio JM, Colborn GL, Weidman TA, Skandalakis JE. Larynx. In: Skandalakis JE (ed) Surgical anatomy. PMP Ltd, Athens, 2004: 229-63.

20. Rossi RL, Cady B. Surgical anatomy. In: Cady B, Rossi RL (eds) Surgery of the thyroid and parathyroid glands, $3^{\text {rd }}$ ed. WB Saunders Company, Philadelphia, 1991: 13-30.

21. Engin O, Ipekci F, Yildirim M, Kulan A, Yagci A, Dalgic A, Calik B. Phrenic-Recurrent Nerve Anastomosis in Animal Models with Unilateral Cutting of the Recurrent Nerve. Indian J Surg 2010;72:362-6. https://doi.org/10.1007/s12262-010-0196-z 